\begin{tabular}{|c|c|c|}
\hline 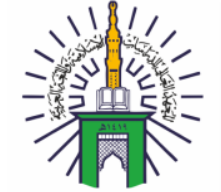 & 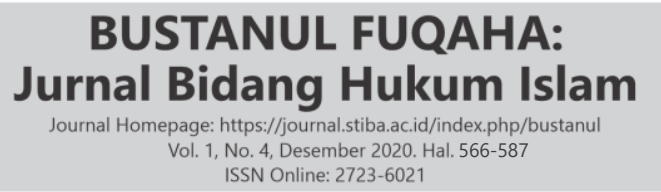 & $\begin{array}{l}\text { Jumal } \\
\text { BUSTANUL } \\
\text { FUQAHA } \\
\text { Jumal Bidang tulum Istam }\end{array}$ \\
\hline
\end{tabular}

\title{
KHIYĀR AL-MAJLIS DAN APLIKASINYA DALAM JUAL BELI MODERN (STUDI KOMPARATIF ANTARA JUMHUR ULAMA DAN IMAM MALIK)
}

\author{
Muhammad Taufan Djafri \\ Sekolah Tinggi Ilmu Islam dan Bahasa Arab (STIBA) Makassar \\ Email: muhtaufandjafri@stiba.ac.id \\ Askar Patahuddin \\ Sekolah Tinggi Ilmu Islam dan Bahasa Arab (STIBA) Makassar \\ Email: askarfatahuddin@stiba.ac.id \\ Muhammad Ridha \\ Sekolah Tinggi Ilmu Islam dan Bahasa Arab (STIBA) Makassar \\ Email: muhammad.ridha2601@gmail.com
}

\begin{abstract}
Keywords :
ABSTRACT

Buying and Selling Online,

Khiyār Al-majlis, Imam Malik

This article aims to find out the jurisprudence khiyār al-majlis according to Imam Malik and Jumhur Ulama, and to know the application of khiyār al-majlis in modern buying and selling. This study uses qualitative methods with library research (library research) with content analysis of the selected data sources. The research results obtained: First, according to the Jumhur Ulama khiyār al-majlis can be done either in person or online. Second, According to the Maliki School of Khiyār al-Majlis it is not allowed and what can be done is Khiyār. Requirements before transactions such as delivery of goods, as well as Khiyār disgrace when a buyer finds a deficiency / defect in the goods that have been purchased. Third, the application of Khiyār al-Majlis in modern buying and selling or online shop in the form of the right to continue or cancel the sale and purchase between the seller and the buyer, this can be done if one of the two requires a khiyar within a certain time and they are still in one transaction until he / she is receive the goods and this is in accordance with the opinion of the jumhur ulama, whereas according to Imam Malik it is not allowed because this can damage the terms of sale and purchase.

Kata kunci :

\section{ABSTRAK}

Jual Beli Online, Khiyār

Al-majlis, Imam Malik
Artikel ini bertujuan untuk mengetahui fikih Khiyār al-Majlis menurut Imam Malik dan jumhur ulama, serta mengetahui penerapan Khiyār al-Majlis dalam jual beli modern. Penelitian ini menggunakan metode kualitatif dengan kajian kepustakaan (library reseach) dengan analisis konten terhadap sumber data yang dipilih. Hasil penelitian yang diperoleh adalah: Pertama, menurut jumhur ulama Khiyār al-Majlis boleh dilakukan baik akad secara langsung maupun secara online. Kedua, menurut Mazhab Maliki Khiyār al-Majlis tidak dibolehkan dan yang dapat dilakukan adalah khiar syarat sebelum terjadinya transaksi seperti pengiriman barang, begitu juga khiar aib ketika pembeli menemukan kekurangan/cacat pada barang yang telah dibeli. Ketiga, penerapan Khiyār al-Majlis dalam jual beli modern atau online shop berupa hak untuk meneruskan atau membatalkan jual beli antara penjual dan pembeli, 


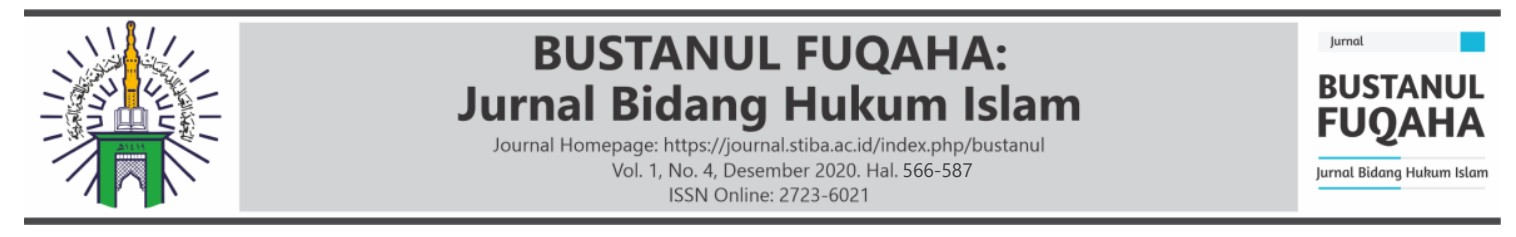

hal ini dapat dilakukan bila salah satu dari keduanya mensyaratkan
adanya khiar dalam tempo tertentu dan mereka masih dalam satu
transaksi sampai ia menerima barangnya dan hal ini sesuai dengan
pendapat jumhur ulama sedangkan menurut Imam Malik
mengatakan tidak boleh karena hal ini dapat merusak syarat jual beli
tesebut.

\section{PENDAHULUAN}

Islam merupakan agama yang memiliki berbagai norma dan aturan bagi para pemeluknya. Islam tidak hanya berkaitan dengan berbagai aturan dan ajaran yang sifatnya hanya ibadah secara vertikal belaka tetapi aturan dan ajaran yang terhimpun dalam segala lini kehidupan, termasuk pada interaksi sosial kemasyarakatan atau bermuamalah. Muamalah yang begitu erat kaitannya dengan kehidupan, interaksi sosisal dalam kemasyarakatan berbangsa dan bernegara tentu membutuhkan norma atau aturan yang mengikat agar tercipta sebuah tatanan masyarakat yang sejahtera. Sebagai umat mayoritas muslim di Indonesia tentunya harus bermuamalah sesuai dengan tunt unan agama Islam yang mulia ini. Tentu pula dalam hal pembelanjaan harta mesti mengindahkan syariat Islam ${ }^{1}$, termasuk dalam jual beli barang atau jasa.

Jual beli adalah bentuk dasar dari kegiatan ekonomi manusia dan merupakan aktivitas yang sangat dianjurkan dalam ajaran Islam. Jual beli merupakan sesuatu yang mubah (boleh). Allah berfirman dalam Qs. Al-Baqarah/2:275,

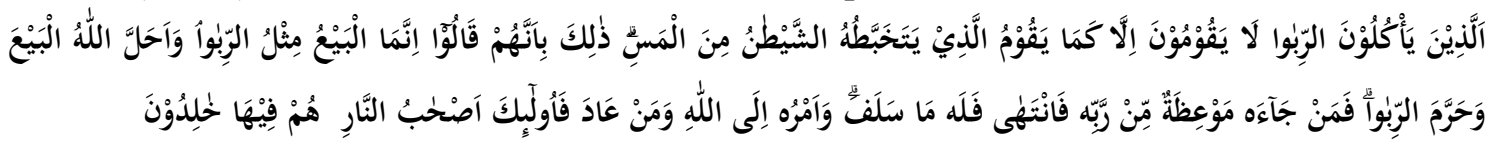

Terjemahnya:

"Orang-orang yang memakan riba tidak dapat berdiri melainkan seperti berdirinya orang yang kemasukan setan karena gila. Yang demikian itu karena mereka berkata bahwa jual beli sama dengan riba. Padahal Allah telah menghalalkan jual beli dan mengharamkan riba. Barangsiapa mendapat peringatan dari Tuhannya, lalu dia berhenti, maka apa yang telah diperolehnya dahulu menjadi miliknya dan urusannya (terserah) kepada Allah. Barangsiapa mengulangi, maka mereka itu penghuni neraka, mereka kekal di dalamnya."

Kegiatan ekonomi dalam Islam, secara khusus pada aktivitas perdagangan dan jual-beli, bukanlah hanya sebatas proses tukar menukar, tetapi juga meliputi harta/barang jual yang halal dan baik, juga praktik usaha halal yang tidak hanya berorientasi pada keuntungan semata tapi juga mengedepankan nilai-nilai dan tata cara jual-beli dalam Islam. Kegiatan berdagang atau berbisnis merupakan aktivitas yang

${ }^{1}$ Iskandar, A., \& Aqbar, K., "Reposisi Praktik Ekonomi Islam: Studi Kritis Praktik Ekonomi Islam di Indonesia”, NUKHBATUL'ULUM: Jurnal Bidang Kajian Islam 5 no. 1 (2019): h. 39.

${ }^{2}$ Kementrian Agama. R.I, "Alquran Terjemah Aljamil,"Alquran (Bekasi: Cipta Bagus Sagara, 2012), h. 275. 


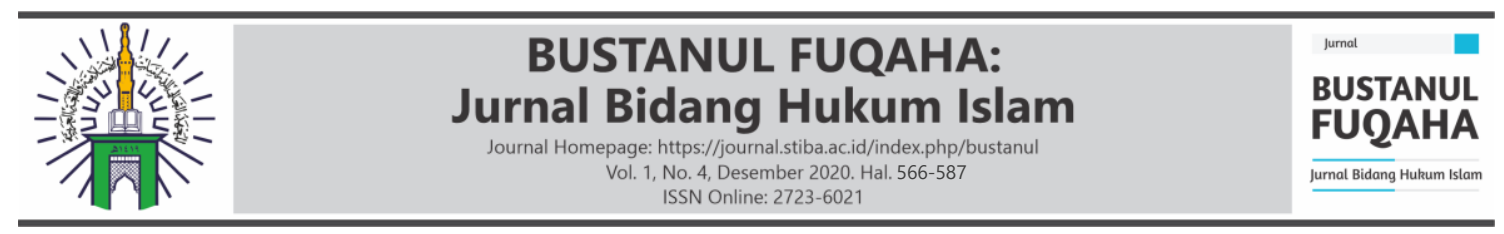

sangat dianjurkan dalam ajaran Islam. Bahkan Rasulullah saw. sendiri pun saat remaja sudah memulai untuk berdagang ke negeri Syam.

Dahulunya sistem jual beli kita kenal dengan istilah sistem barter dan transaksi perdagangan dilakukan dengan cara langsung dan berhadap-hadapan, namun dalam perkembangannya di zaman kontemporer ini di mana teknologi semakin canggih, orang bisa melakukan perniagaan dan transaksi melalui teknologi yang canggih atau biasa disebut dengan jual beli online 3 . Jadi, perdagangan sejak zaman Nabi saw. telah di lakukan, namun bentuk transaksi atau ijab kabul pada zaman itu di lakukan secara langsung. Oleh karena itu, Khiyär al-Majlis (hak untuk membatalakan akad jual beli) dalam transaksi jual beli sah setelah transaksi antara keduanya di lakukan di tempat tersebut dan boleh melakukan Khiyär al-Majlis sebelum mereka berpisah dari tempat itu, sebagaimana Rasulullah saw. bersabda:

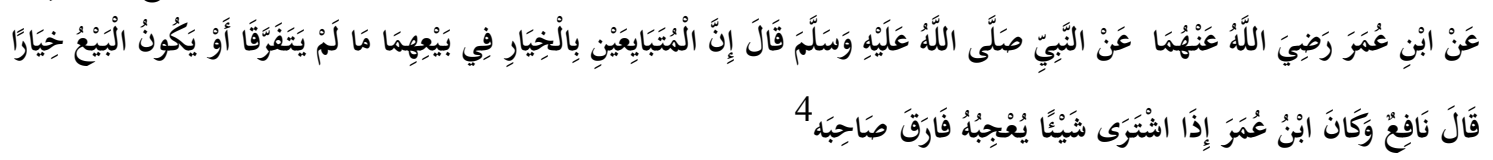

Artinya:

“Dari Ibnu 'Umar radhiallahu'anhuma dari Nabi saw. bersabda, "Dua orang yang melakukan jual beli boleh melakukan khiar (pilihan untuk melangsungkan atau membatalkan) dalam jual beli selama keduanya belum berpisah, atau jual beli menjadi khiar (terjadi dengan pilihan) ". Nafi' berkata, "Adalah Ibnu 'Umar radhiallahu'anhuma bila membeli sesuatu, baru menganggapnya telah terjadi jual beli bila sudah berpisah dari penjualnya."

Berbeda halnya dengan jual beli modern saat ini yang dilakukan secara $E$ Commerce dan E-bussines, atau semisal berbasis aplikasi Go-Pay dan $O V O^{5}$. Menurut Microsoft Encarta reference library, E-commerce adalah perdagangan barang dan jasa dengan bantuan internet atau jaringan dengan computer lain (the exchanges of goods and services by means of the internet or other computer networks), sedangkan Ebussines sendiri adalah proses di mana sebuah organisasi atau perusahaan bisnis melakukan proses tersebut pada saluran jaringan pada sebuah media elektronik ${ }^{6}$.

Dari dua definisi tersebut terlihat jelas bahwa yang membedakan E-commerce dan E-bussines adalah pada pola transaksi dan pembayarannya. E-commerce sendiri memberikan sedikit ruang alternatif dari segi pembayaran bagi para konsumen, yaitu dengan diberlakukannya sistem pembayaran offline, atau dengan kata lain proses Negara."

${ }^{3}$ Tira Nur Fitria, "Bisnis Jual Beli Online (Online Shop) Dalam Hukum Islam Dan Hukum

${ }^{4}$ Sunan Abi Daud, “Sunan Abi Daud,” in باب خيار المتبيعان, n.d., h.327, https://www.google.com.

${ }^{5}$ Wijaya, H., "Takyif Fiqh Pembayaran Jasa Transportasi Online Menggunakan Uang Elektronik (Go-Pay Dan OVO)”, NUKHBATUL'ULUM: Jurnal Bidang Kajian Islam 4 no. 2 (2018): h. 187.

${ }^{6}$ Novianto Languyu, "Kedudukan Hukum Penjual Dan Pembeli Dalam Bisnis Jual Beli Online." Lex Et Societatis 3, no. 9 (2015): 94-100. 


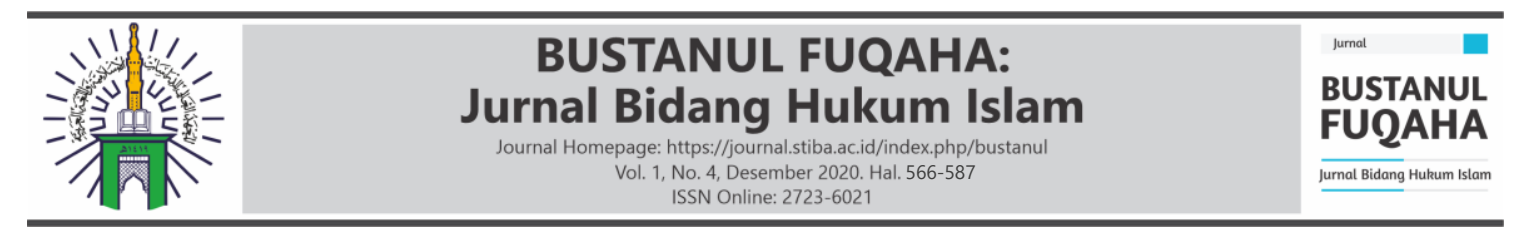

pembayaran dan pengiriman barang dan jasa dapat dilakukan diakhir kesepakatan, sedangkan E-bussines mengharuskan proses dan transaksi tersebut dilakukan pada saluran jaringan di sebuah media elektronik ${ }^{7}$.

Dengan demikian, dari uraian latar belakang di atas penulis tertarik untuk mengkaji Khiyār al-Majlis (Studi Komparatif Antara Jumhur Ulama dan Imam Malik) dan Aplikasinya Dalam Jual Beli Modern. Adapun sebagai upaya untuk menjelaskan hal tersebut, artikel ini menggunakan pendekatan kualitatif, dan jenis data yang dipakai mengarah pada data-data kualitatif dengan menitikberatkan pada persoalan-persoalan mendalam, meliputi: 1) data tentang Khiyār al-Majlis menurut jumhur ulama dan Imam malik; dan 2) Hukum Khiyār al-Majlis yang berkaitan dengan jual beli modern.

Desain pendekatan kualitatif yang digunakan adalah historis-deskriptif dan yuridis-normatif. Yang dimaksudkan dengan penelitian historis adalah usaha untuk mempelajari dan menggali fakta-fakta dan menyusun kesimpulan mengenai peristiwaperistiwa masa lampau ${ }^{8}$. Dan penelitian yang bersifat deskriptif dalam KBBI adalah bersifat menggambarkan apa adanya ${ }^{9}$. Sedangkan desain pendekatan yuridis-normatif yaitu suatu penelitian yang secara deduktif dimulai analisis terhadap pasal-pasal dalam peraturan perundang-undangan yang mengatur terhadap permasalahan di atas.

Penelitian hukum secara yuridis maksudnya penelitian yang mengacu pada studi kepustakaan yang ada atau pun terhadap data sekunder yang digunakan. Sedangkan bersifat normatif maksudnya penelitian hukum yang bertujuan untuk memperoleh pengetahuan normatif tentang hubungan antara satu peraturan dengan peraturan lain dan penerapan dalam praktiknya. Pendekatan yuridis-normatif adalah pendekatan yang menelaah hukum sebagai kaidah yang dianggap sesuai dengan penelitian yuridisnormatif atau penelitian hukum tertulis ${ }^{10}$.

Pada metode ini digunakan langkah-langkah pengumpulan sumber data primer dan sekunder. Sumber data primer yang digunakan adalah Kitab Bidayatu al-Mujtahid dan Kitab Al-Muwatta'. Sumber data sekunder yang digunakan adalah buku-buku yang mendukung pengkajian sumber data primer di atas seperti Kitab Subul al-salām dan Kitab Sahih Al-Bukhari.

\footnotetext{
${ }^{7}$ Novianto Languyu, “ Kedudukan Hukum Penjual Dan Pembeli Dalam Bisnis Jual Beli Online,” (2015): 94-100.

8"Penelitian-Menurut-Metode-Historis,"

2013 https://www.slideshare.net/kepliedduu/penelitian-menurut-metode-historis.

9“Arti-Kata Deskriptif,” n.d., https://jagokata.com/arti-kata/deskriptif.html.

10“Metode-Penelitian-Pendekatan-Yuridis-Normatif," n.d., https://docplayer.info/52868151-Imetode-penelitian-pendekatan-yuridis-normatif-adalah-pendekat an-yang-menelaah-hukumsebagai.html.
} 


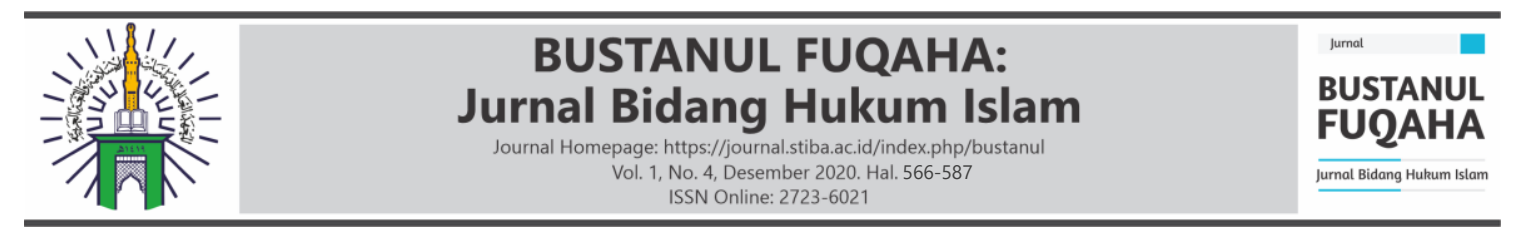

\section{PEMBAHASAN}

\section{Khiyār al-Majlis menurut Jumhur Ulama}

Khiar artinya mencari yang terbaik dari dua pilihan, antara meneruskan atau membatalkan jual beli ${ }^{11}$. Dalil dibolehkannya khiar, hal tersebut adalah yang menjadi pendapat jumhur ulama Rasulullah saw. bersabda:

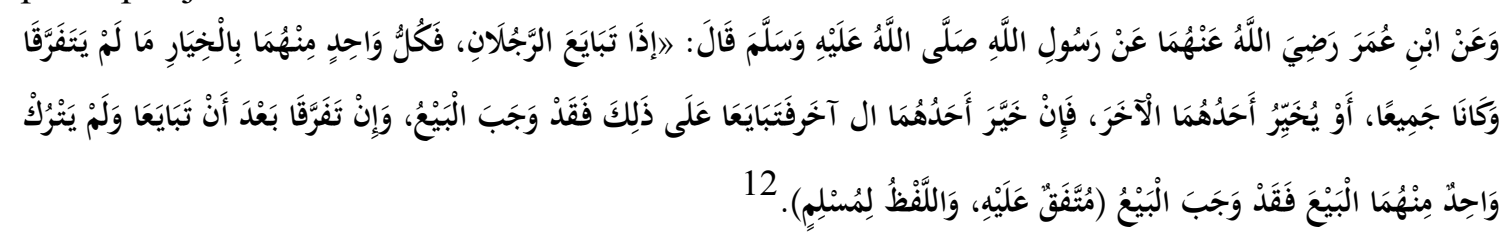

Artinya:

"Dari Ibnu Umar ra., dari Rasulullah saw. bersabda, "Apabila dua orang melakukan jual beli, maka masing-masing dari keduanya mempunyai hak khiar (memilih antara membatalkan atau meneruskan jual beli) selama mereka belum berpisah atau masih bersama; atau jika salah seorang di antara keduanya menentukan khiar kepada yang lainnya. Jika salah seorang menentukan khiar pada yang lain, lalu mereka berjual beli atas dasar itu, maka jadilah jual beli itu. Jika mereka berpisah setelah melakukan jual beli dan masing-masing dari keduanya tidak mengurungkan jual beli, maka jadilah jual beli itu." (Muttafaq Alaih, dan lafazh hadis ini menurut riwayat Muslim)

Dalam hadis ini terdapat petunjuk adanya Khiyār al-Majlis bagi kedua pihak pelaku jual beli sampai keduanya berpisah badan. Jumhur ulama dari sekelompok sahabat di antaranya 'Ali bin Abi Ṭalib, Ibnu Abbas dan Ibnu Umar dan lainnya. Itu juga yang dipegang oleh kebanyakan kalangan tabiin dan Al-Syāfi 'i, Ahmad, Ishaq dan Imam Yahya mereka mengatakan: perpisahan yang membatalkan khiar yaitu sesuatu yang dinamakan perpisahan secara adat kebiasaan. Seperti dalam rumah yang sempit dengan cara salah seorang keluar darinya, dan dalam rumah yang besar dengan cara berpindah dari tempatnya ke tempat yang lain dengan dua langkah atau tiga langkah. Perpisahan tersebut ditunjukkan dengan perbuatan Ibnu Umar yang terkenal. Bila kedua pihak semuanya berdiri dan pergi bersama-sama maka hak khiar tetap ada. Mazhab ini berargumentasi dengan hadis yang Muttafaq 'Alaih ini.

Jumhur ulama berpendapat tidak ada khiar dalam penipuan berdasarkan keumuman hadis dan terjadi jual beli tanpa dibedakan antara tertipu atau tidak. Mereka mengatakan: hadis dalam bab ini terjadi khiar disebabkan kelemahan akal orang tersebut.

\footnotetext{
${ }^{11}$ Imam Aș-Ṣan’ānī, “Subulus Salam,” Jilid II Bab Khiyār (Memilih) (Darul Hadist, n.d.), h.45.

${ }^{12}$ Imam Ash-shsn'ani, "Subulus Salam Syarah Bulughul Maram," [Shahih, Al-Bukhari (2107), Dan Muslim (1531)], 2008, h. 388.
} 


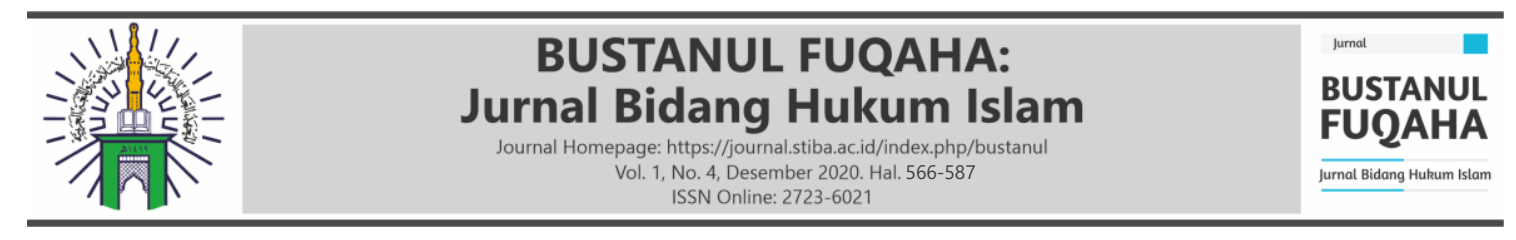

Hanya saja kelemahan tersebut tidak keluar dari batasan tamyiz sehingga perilakunya sama seperti perilaku anak kecil dan diizinkan memiliki khiar karena tertipu ${ }^{13}$.

\section{Khiyār al-Majlis Menurut Imam Malik}

Menurut Imam Malik tidak ada Khiyār al-Majlis. Bahkan saat kedua pelaku akad berpisah secara percakapan, maka tidak ada khiar kecuali apa yang disyaratkan ${ }^{14}$. Beliau Rahimahulläh berargumentasi dengan firman Allah Q.s. Al-Nisä'/4:29 dan Qs. AlBaqarah/3:282,

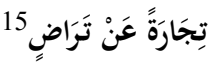

Terjemahnya:

"Jual beli atas suka sama suka".

Terjemahnya:

وَأَنْهُهِدُوا إِذَاً تَبَايَتْتُمْ16

"Dan persaksikanlah saat kalian berjual beli".

Mereka mengatakan: persaksian bila terjadi setelah berpisah badan tidak sesuai dengan perintah Allah, dan bila terjadi sebelumnya maka tidak tepat pada tempatnya.

Sedangkan dalam hadis Nabi saw. berbunyi:

$$
\text { إذَا اخْتَلَفَ الْبَيْعَانِ فَالْقَوْلُ قَوَلْ الْبَائع }
$$

Artinya:

"Apabila berbeda pendapat kedua pelaku jual beli maka ucapan yang diterima yaitu ucapan penjual (belum diperinci)".

Ayat tersebut masih mutlak dikhususkan dengan hadis seperti khiar syarat. Begitu pula halnya hadis dan ayat persaksian dimaksudkan saat akad jual beli. Hal tersebut tidak menafikan adanya Khiyār al-Majlis seperti halnya tidak menafikan semua jenis khiar. Mereka mengatakan: hadis tersebut mansukh (terhapus) dengan hadis:

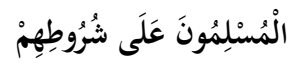

Artinya:

\section{"Kaum muslimin sesuai dengan syarat mereka."}

Maka khiar setelah terjadi jual beli akan merusak syarat ${ }^{17}$. Yang dijadikan landasan oleh ulama yang melarangnya adalah bahwa hal tersebut merupakan suatu penipuan, dan pada dasarnya adalah tetap berada pada jual beli kecuali ada dalil yang

\footnotetext{
${ }^{13}$ Imam Aș-Ṣan'ānī, "Subulus Salam Syarah Bulughul Maram,” Jilid II Bab Khiyār (Memilih) (Darul Hadist, n.d.), h. 48.

${ }^{14}$ Imam Ash-Shan'ani, "Subulus Salam,” Bab Khiyār (Memilih) (Darul Hadist, n.d.), h. 46.

${ }^{15}$ Kementrian Agama R.I., 'Alquran Terjemah Aljamil', Alquran (Bekasi: Cipta Bagus Sagara, 2012), h. 29. 2012), h. 282.

${ }^{16}$ Kementrian Agama R.I., 'Alquran Terjemah Aljamil', Alquran (Bekasi: Cipta Bagus Sagara,

${ }^{17}$ Imam Ash-shan'ani, “Subulus Salam,” Jilid II Bab Khiyar (Memilih) (Darul Hadist, n.d.), 46.
} 


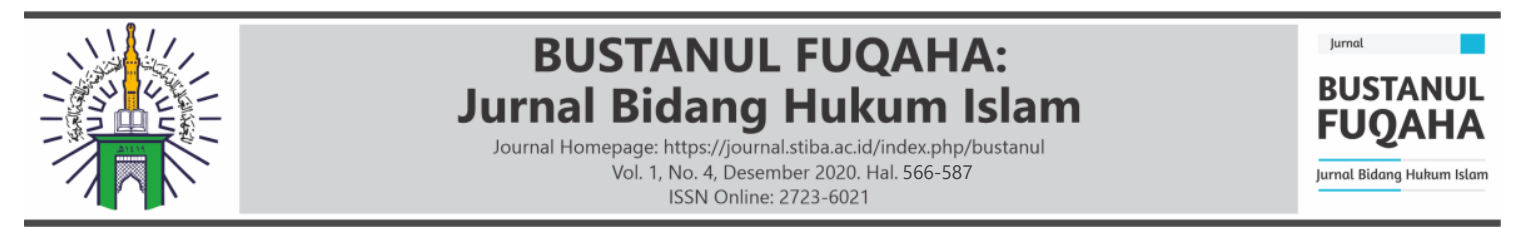

menunjukkan dibolehkannya jual beli dengan syarat adanya khiar dari kitab Allah atau sunah yang kuat atau ulama. Mereka berkata, "Hadis Habban kemungkinan tidak sahih atau hal tersebut merupakan kekhususan bagi dirinya karena ia telah mengadu kepada Rasulullah saw. bahwa ia telah tertipu dalam jual beli." Mereka berkata, "Adapun hadis Ibnu Umar dan perkataannya dalam hadis tersebut, 'kecuali jual beli dengan khiar, maka beliau telah menafsirkan makna yang dimaksud dengan lafazh ini yaitu yang disebutkan padanya dengan lafazh yang lain yaitu .Salah seorang di antara mereka berdua mengatakan kepada sahabatnya, 'Pilihlah'."18 Rasulullah saw. bersabda:

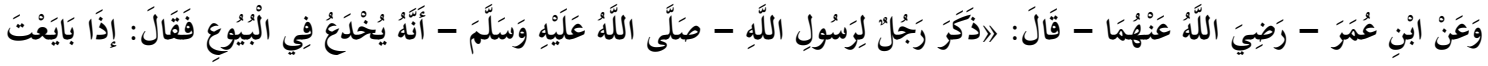

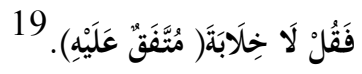

Artinya:

"Ibnu Umar ra. berkata, "Ada seseorang mengadu kepada Rasulullah saw. bahwa ia tertipu dalam jual beli Lalu beliau bersabda, "Jika engkau berjual beli, katakanlah, "Jangan melakukan tipu daya". (Muttafaq 'Alaih)

Ishaq menambahkan dalam riwayat Yunus bin Bakir dan Abdi al-A'la.

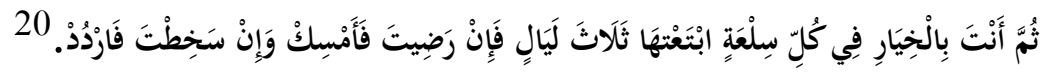

Artinya:

"Kemudian engkau mempunyai hak pilih setiap barang yang engkau beli selama tiga malam, bila engkau rela maka peganglah (ambillah) dan bila engkau benci maka kembalikanlah."

Orang tersebut masih hidup hingga periode Utsman saat itu berusia 130 tahun. Pada zaman Utsman banyak orang-orang bilang membeli sesuatu dikatakan padanya, engkau tertipu dengannya maka kembalilah dan saksikanlah dengan seorang sahabat bahwa Nabi saw. memberikannya hak pilih selama tiga hari sehingga dirham miliknya dikembalikan.

Hadis tersebut sebagai dalil adanya hak pilih saat ditipu dalam jual beli. Dalam hal ini ulama berbeda pendapat menjadi dua pendapat, yaitu: Pertama, tetapnya khiyār saat ditipu. Itulah pendapat yang dipegang oleh Imam Malik, tetapi hal tersebut terjadi bila penipuan tersebut kelewatan pada orang yang tidak mengetahui harga barang. Dari kalangan Malikiyah membatasi kadar penipuan dengan tiga kali harga. Semoga saja mereka mengambil pembatasan pada hal yang menyerahkan kemutlakan jenis penipuan secara umum. Oleh karena itu, penipuan kecil biasanya dapat ditoleransi. Untuk itu, siapa yang menerima dengan terjadinya penipuan setelah mengetahuinya tidak disebut

\footnotetext{
${ }^{18}$ Ibnu Rusyd, "Bidāyatul Mujtahid," Bab Khiyār (Memilih), n.d., h. 201.

${ }^{19}$ Imam Aș-Șan'ānī, "Subulus Salam," in [Shahih, Al-Bukhari (2117) Dan Muslim (1533)] Bab Khiyār (Memilih) (Darul Hadist, n.d.), h.48.

${ }^{20}$ Imam Aș-Șan'ānī, "Subulus Salam," [Al-Baihaqi (5/273) Dan Ad-Daraquthni (3/55, 56)] Bab Khiyār (Memilih) (Darul Hadist, n.d.), h. 48.
} 


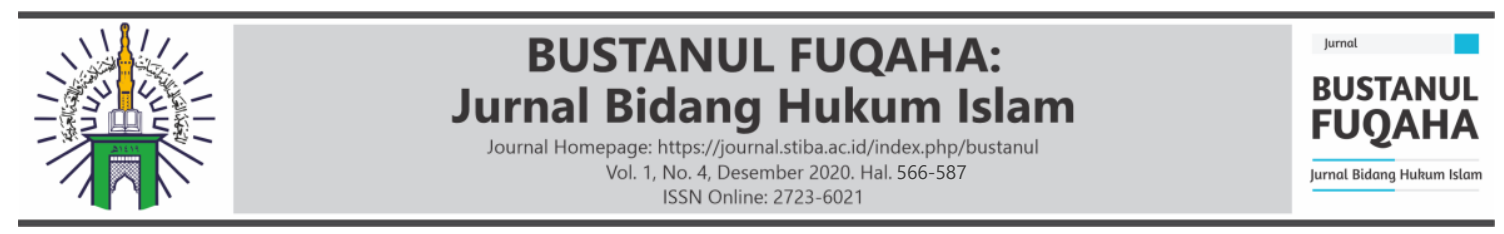

sebagai bentuk penipuan. Hanya saja sebagai bentuk keteledoran dalam berjual beli yang pelakunya dipuji oleh Rasulullah saw. dan dinyatakan bahwa Allah mencintai seorang yang mudah menjual dan membeli ${ }^{21}$.

\section{Macam-Macam Khiar}

\section{Khiyār al-Majlis}

Khiyār al-Majlis yaitu tempat transaksi, dengan demikian Khiyār al-Majlis berarti hak pelaku transaksi untuk meneruskan atau membatalkan akad selagi mereka berada dalam tempat transaksi dan belum berpisah. Apabila keduanya telah berpisah dari tempat akad tersebut, maka Khiyār al-Majlis tidak berlaku lagi (batal). Khiar ini adalah Khiar yang ditetapkan oleh syarak bagi setiap pihak yang bertransaksi semata karena adanya aktivitas akad, selama para pihak masih berada ditempat transaksi. ${ }^{22}$ Khiyār al-Majlis berlaku dalam berbagai macam jual beli, seperti pengelolaan barang, jual beli makanan dengan makanan, akad pemesanan barang (salam), tauliyah, syirkah, dan sulh (perdamaian) dengan memberikan sejumlah kompensasi. Demikian ini sesuai dengan makna tekstual sabda Rasulullah saw. dalam hadis riwayat Al-Bukhari, Muslim, Malik, dan lain-lain dari Ibnu 'Abbās sebagai berikut:

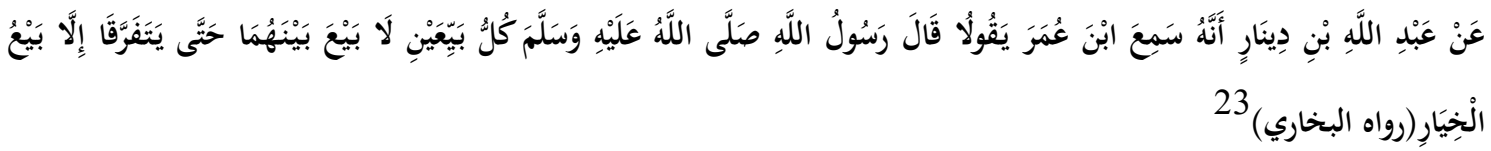

Artinya:

"Dari 'Abdullah bin Dinār bahwa beliau mendengar Ibnu 'Umar berkata: Rasulullah saw. bersabda: setiap dua orang yang berjual beli, tidak ada jual beli bagi keduanya sehingga mereka berpisah kecuali jual beli dengan Khiar" (HR. Al-Bukhari).

Hadis di atas menjelaskan bahwa jadi atau tidaknya transaksi jual beli harus dilakukan pada saat terjadinya transaksi tersebut tidak boleh ditunda di lain waktu, kecuali kalau transaksinya merupakan transaksi bersyarat. Kalau transaksinya bersyarat atau dengan garansi, maka apabila barang yang dibeli tidak sesuai dengan ciri-cirinya, atau sebelum waktu garansinya habis barang tersebut sudah rusak, tentu saja boleh dikembalikan. Selain itu, hadis di atas juga menjelaskan bahwa ketika jual beli telah berlangsung, masing-masing pihak berhak melakukan khiyār antara membatalkan atau meneruskan akad hingga mereka berpisah atau menentukan pilihan. ${ }^{24}$ Perpisahan atau

\footnotetext{
${ }^{21}$ Imam Aṣ-Ṣan’ānī, “Subulus Salam,” Bab Khiyār (Memilih) (Darul Hadist, n.d.), h. 48.

${ }^{22}$ Ela Eliska, "Analisisis Eksistensi Khiyār Dalam Akad Jual Beli (Studi Perbandingan Empat Mazhab) Skripsi (Banda Aceh: Fak. Syari’ah Dan Hukum UIN Ar-Raniri, 2017), h. 104. 25.

${ }^{23}$ Abi Abdillah Muhammad, "Shahih Bukhari Juz III," Beirut: Dar Al-Kutub Al-Ilmiyah, 1992, h.

${ }^{24}$ Ela Eliska, “Analisisis Eksistensi Khiyār Dalam Akad Jual Beli (Studi Perbandingan Empat Mazhab) Skripsi (Banda Aceh: Fak. Syari’ah Dan Hukum UIN Ar Raniri, 2017), h. 105.
} 


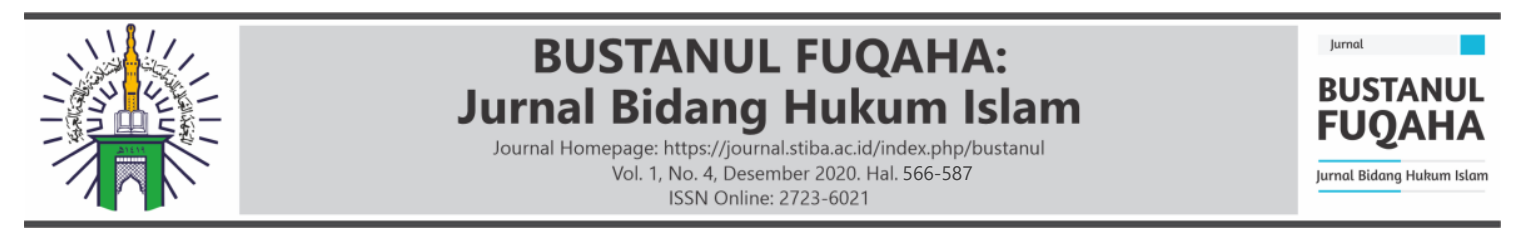

tafarruq terjadi bila dua belah pihak telah meninggalkan tempat transaksi. Jaraknya kirakira jika seseorang menyapa orang lain dalam kondisi normal, suaranya tidak terdengar.

Apabila keberadaan para pihak yang bertransaksi di majelis akad berlangsung lama, atau mereka berdiri dan berjalan di berbagai tempat, khiyār keduanya berlaku lebih lama, meskipun lebih dari tiga hari. Batasan perpisahan mengacu kepada kebiasan yang berlaku dalam masyarakat ('urf). Suatu tindakan yang dikatagorikan sebagai "perpisahan" oleh masyarakat berkonsekuensi terhadap ketetapan hukum akad, jika tidak demikian akad tidak berkekuatan hukum tetap. Sebab sesuatu yang tidak memliki batasan definitif secara syarak maupun bahasa, dikembalikan pada ketentuan yang berlaku di masyarakat ${ }^{25}$.

\section{Khiyār al-Syant (Khiar Syarat)}

Khiar syarat yaitu hak pilih yang ditetapkan bagi salah satu pihak yang berakad atau keduanya atau bagi orang lain untuk meneruskan atau membatalkan jual beli selama masih dalam tenggang waktu yang ditetapkan. Adanya khiar syarat menurut syariat Islam, diterangkan dalam berbagai hadis. Menurut riwayat Bukhari dan Muslim, Ibnu 'Umar memberitakan bahwa ada seorang laki-laki melaporkan kepada Nabi saw. bahwa dia ditipu orang dalam jual beli. Maka bersabdalah Nabi saw. "Jika kamu berjual beli, maka katakanlah: tidak (jangan) ada tipuan, kemudian engkau mempunyai hak khiar selama tiga malam"26. Kerusakan yang terjadi pada jual beli ini kembali kepada kerusakan yang terjadi karena penipuan. Tetapi karena dikandung oleh nas, maka harus dibuat salah satu bagian jual beli yang rusak dengan batasan tersendiri. Yang mendasari perbedaan pendapat para ulama dalam bab ini yaitu tiga hadis:

Pertama, hadis Jābir ra., dia berkata:

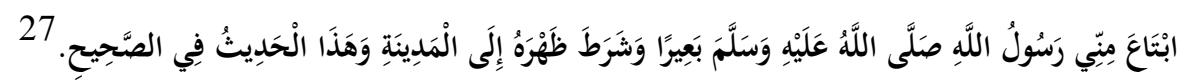

Artinya:

"Rasulullah saw. membeli seekor unta dariku dan mensyaratkan agar beliau menaikinya sampai ke Madinah. 'Hadis ini terdapat dalam kitab Ash-shahih'."

Kedua: yaitu hadis Barīrāh, bahwa Rasulullah saw. bersabda,

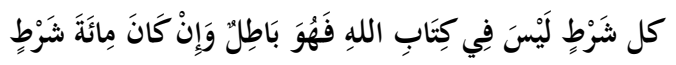

\footnotetext{
${ }^{25}$ Wahbah Az- Zuhaili, "Fikih Imam Syafi'i," n.d., h. 676-677.

${ }^{26}$ Dewi Sri Indriati, "Penerapan Khiyār Dalam Jual Beli," Jurnal Ilmiah Al-Syir'iah 2, no. 2 (2016)

${ }^{27}$ Ibnu Rusyd, "Bidayatul Mujtahid," Muttafaq 'Alaih.HR. Al Bukhari (2718), Muslim (715), Ahmad (3/303), n.d., h. 177.
} 


\begin{tabular}{|c|c|c|}
\hline 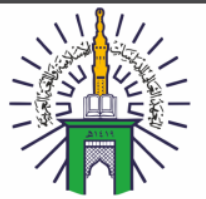 & 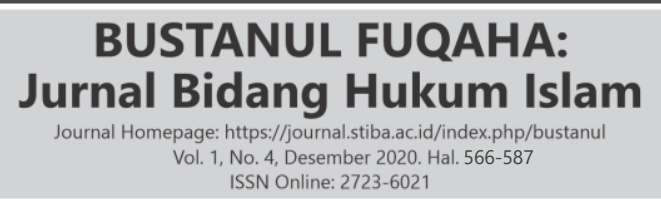 & $\begin{array}{l}\text { Jumal } \\
\text { BUSTANUL } \\
\text { FUQAHA } \\
\text { lumana Bidang tukuum sslam }\end{array}$ \\
\hline
\end{tabular}

Artinya:

"Setiap syarat yang tidak terdapat dalam kitab Allah, maka syarat tersebut batal, meskipun seratus syarat. Hadis ini disepakati tentang keshahihannya ${ }^{28}$."

Ketiga, hadis Jābir, dia berkata,

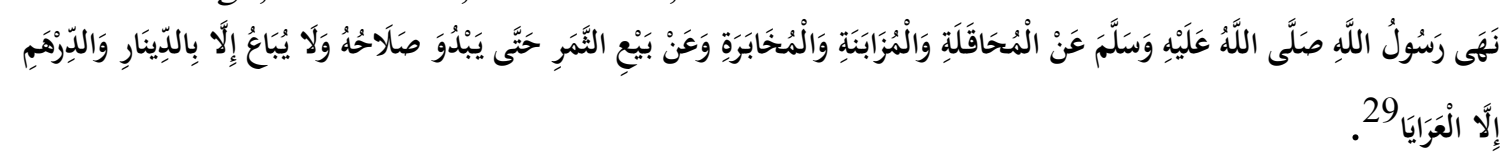

Artinya:

"Rasulullah saw. melarang dari jual beli Muhāqalah (jual beli buah yang masih dalam tangkainya dan belum nampak kelayakannya), Muzābanah, Mukhābarah (bagi hasil tanaman), mu'àwamah (penjualan tahunan) dan tsu-nya (pengecualian), beliau memberikan keringanan pada Jual beli 'aràya."

Ulama berbeda pendapat karena pertentangan di antara hadis-hadis tentang jual beli dan syarat:

a. Sekelompok ulama mengatakan, jual beli rusak dan syaratnya juga rusak. Di antara ulama yang mengemukakan pendapat ini adalah Syafii dan Abu Hanifah.

b. Sekelompok ulama mengatakan bahwa jual beli dibolehkan dan syaratnya juga dibolehkan. Di antara ulama yang mengemukakan pendapat ini adalah Ibnu Abi Syibrimah. Dan sekelompok ulama lain mengatakan jual beli dibolehkan dan syaratnya batal. Di antara ulama yang mengemukakan pendapat ini adalah Ibnu Abi Laila.

c. Ahmad berpendapat jual beli dibolehkan dengan satu syarat, dan jika dengan dua syarat maka tidak dibolehkan.

Menurut Malik, syarat itu terbagi menjadi tiga bagian: syarat-syarat yang batal bersama jual beli, syarat-syarat yang dibolehkan bersama jual beli dan syarat-syarat yang batal sedangkan jual beli tetap sah. Diperkirakan ada syarat keempat menurutnya yaitu di antara syarat-syarat tersebut ada syarat yang jika orang yang membuatnya berpegang dengan syaratnya, maka jual belinya menjadi batal dan jika meningalkannya, maka jual belinya dibolehkan. Untuk membedakan secara jelas di dalam mazhabnya antara keempat macam syarat ini cukup sulit, kebanyakan fukaha telah berusaha membedakannya, hanya saja semua itu kembali kepada banyaknya kandungan dari syarat-syarat tersebut yaitu berupa dua macam kerusakan yang merusak sahnya jual beli.

\footnotetext{
${ }^{28}$ Ibnu Rusyd, "Bidayatul Mujtahid," Muttafaq 'Alaih.HR. Al Bukhari (2168), Muslim (1504), Abu Daud (3929), ." AtTirmidzi (2124), An-Nasa'i (71305), Ahmad (6/81,271), Abu Ya'la 94435), Dan Al Baihaqi (10/338)., n.d., h.178.

${ }^{29}$ Ibnu Rusyd, "Bidayati Mujtahid," HR. Muslim, Hadis Shahih, h. 178.
} 


\begin{tabular}{|c|c|c|}
\hline 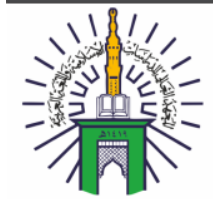 & 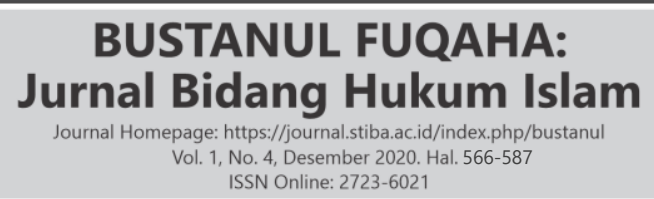 & $\begin{array}{l}\text { Jumal } \\
\text { BUSTANUL } \\
\text { FUQAHA } \\
\text { Jumal Bidang thutum Isiom }\end{array}$ \\
\hline
\end{tabular}

Keduanya yaitu riba dan penipuan. Kepada sedikitnya dan kepada pertengahan antara hal itu, atau kepada sesuatu yang mengurangi kepemilikan.

Jika masuknya hal-hal ini dalam jual beli sangat banyak dari segi syarat, maka bisa membatalkannya dan membatalkan syarat tersebut. Jika masuknya sedikit, maka hal itu bisa membolehkannya dan membolehkan syarat yang terdapat di dalamnya. Sedangkan yang pertengahan, bisa membatalkan syarat dan membolehkan jual beli. Para pengikut Malik berpendapat bahwa pendapatnya adalah pendapat yang paling utama, karena pendapatnya menghimpun semua hadis-hadis yang ada. Adapun menghimpun hadis-hadis yang ada lebih baik dari mengunggulkan salah satunya.

Para ulama kontemporer di antara pengikut Malik dalam hal ini memiliki perincian yang hampir sama. Di antara mereka adalah Al Mazari dan Al Bāji. Perinciannya mengatakan bahwa syarat dalam jual beli terjadi dalam dua bentuk: Pertama, mensyaratkannya setelah habis kepemilikan, seperti orang yang menjual budak wanita atau budak laki-laki dan mensyaratkan bahwa kapan dia dimerdekakan, maka waIa' (hak atas budak karena memerdekakannya) menjadi miliknya bukan milik si pembeli. Contoh seperti ini mereka mengatakan, akadnya sah dan syaratnya batal berdasarkan hadis Barirah. Kedua, mensyaratkan suatu syarat yang terjadi pada masa kepemilikan. Mereka mengatakan, ini terbagi menjadi tiga macam: (1) kemungkinan mensyaratkan manfaat untuk dirinya pada barang yang dijualnya; (2) kemungkinan mensyaratkan kepada si pembeli larangan mempergunakan barang tersebut secara umum atau khusus; dan (3) kemungkinan mensyaratkan untuk melakukan suatu makna pada barang yang dijual. Ini juga terbagi menjadi dua bagian; pertama, salah satu makna di antara makna-makna kebaikan; dan kedua, makna yang bukan termasuk kebaikan.

Jika mensyaratkan untuk dirinya suatu manfaat yang mudah yang tidak melarang tindakan pada asal jual beli, seperti menjual sebuah rumah dan mensyaratkan agar dia menempatinya dalam masa yang tidak lama seperti satu bulan dan pendapat lain mengatakan satu tahun, maka hal itu dibolehkan berdasarkan hadis Jābir. Sedangkan mensyaratkannya untuk melarang dari tindakan yang khusus atau umum, maka hal itu tidak dibolehkan karena termasuk jual beli tsunya, seperti menjual seorang budak wanita dengan syarat agar tidak menggaulinya atau tidak menjualnya. Adapun mensyaratkan suatu makna di antara makna-makna kebaikan, seperti pemerdekaan: jika mensyaratkan untuk disegerakan, hal itu dibolehkan menurutnya dan jika ditunda, maka hal itu tidak dibolehkan karena besarnya penipuan dalam hal ini. Malik berpendapat bahwa ini termasuk penipuan yang sedikit, maka dia membolehkannya untuk masa yang sebentar dan tidak membolehkannya pada masa yang lama.

Dari bab ini terdapat jual beli 'urban (uang muka). Jumhur ulama berbagai negeri berpendapat bahwa hal itu tidak dibolehkan. Adapun yang diriwayatkan dari sekelompok ulama dari kalangan tabiin bahwa mereka membolehkannya, di antaranya Mujāhid, Ibnu Sīrīn, Nāfi ' bin Al Hārits dan Zaid bin Aslam. Bentuknya yaitu seseorang membeli sesuatu, harga yang telah diberikan termasuk harga barang tersebut dan jika 


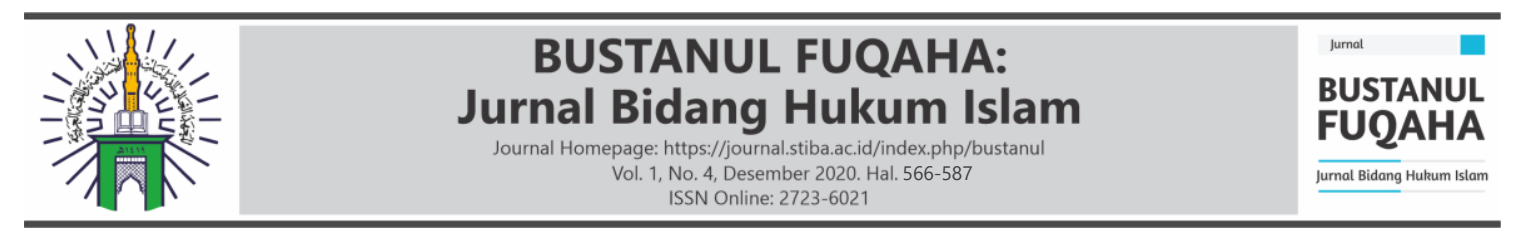

jual belinya tidak berlangsung, maka si pembeli meninggalkan sebagian harga yang telah diberikan kepada si penjual dan tidak memintanya kembali. Hanya saja jumhur berpendapat untuk melarangnya karena hal itu termasuk bab penipuan, terlarang serta memakan harta tanpa ada penggantinya. Zaid mengatakan bahwa Rasulullah saw. membolehkannya, dan para ahli hadis mengatakan, riwayat tersebut tidak dikenal dari Rasulullah saw ${ }^{30}$.

\section{Khiyar al-'Aib (Khiar Aib)}

Khiar Aib (cacat) yaitu hak untuk membatalkan atau melangsungkan jual beli bagi kedua belah pihak yang berakad apabila terdapat suatu cacat pada obyek yang diperjual belikan. Dari Ḥākim bin Ḥizām, Nabi saw. pernah menerangkan:

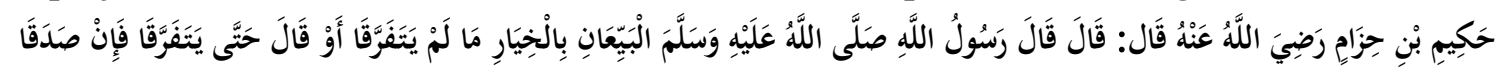

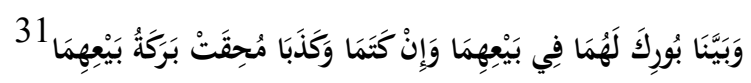

Artinya:

"Hākim bin Hizām ra. berkata; Rasullah saw. bersabda, "Dua orang yang melakukan jual beli boleh melakukan Khiar (pilihan untuk melangsungkan atau membatalkan jual beli) selama keduanya belum berpisah", atau sabda beliau, "Hingga keduanya berpisah. Jika keduanya jujur dan menampakkan dagangannya maka keduanya diberkahi dalam jual belinya dan bila menyembunyikan dan berdusta maka akan dimusnahkan keberkahan jual belinya"."

Ada kalanya seseorang membeli barang yang cacatnya baru diketahui beberapa waktu kemudian setelah akad jual bei itu berlangsung. Apabila terjadi hal semacam itu, maka pihak pembeli berhak mengembalikan barang dan menerima kembali liangnya dari pihak penjual. Yang menjadi dasar tentang adanya pengembalian karena cacat yaitu firman Allah swt. (Q.S. Al-Nisā'/4: 2):

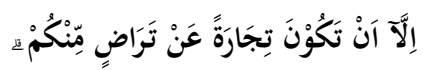

Artinya:

“Kecuali dengan jalan perniagaan yang berlaku dengan suka sama-suka di antara kamu"32.

Itulah yang disebut "khiar aib”, yakni hak mengembalikan barang yang bercacat dan sudah diterangkan oleh pihak penjual sebelum transaksi terjadi, lalu pembeli rida, maka sudah tentu hak khiar aib itu sudah terhapus. Tetapi apabila barang yang cacatnya baru diketahui setelah akad jual beli terjadi. Maka ada tiga alternatif bagi pembeli:

\footnotetext{
${ }^{30}$ Ibnu Rusyd, "Bidayatul Mujtahid,” Bab Syarat, n.d., h.177-181.

${ }^{31}$ Imam Bukhari, "Shahih Bukhari," Bab: Jika Pembeli Melakukan Khiayar, Apakah Jual Beli Boleh Dilakkan?, n.d., hadis ke 1972. h. 29 .

${ }^{32}$ Kementrian Agama. R.I, “Alquran,” Alquran Terjemah Aljamil (Cipta Bagus Sagara, 2012),
} 


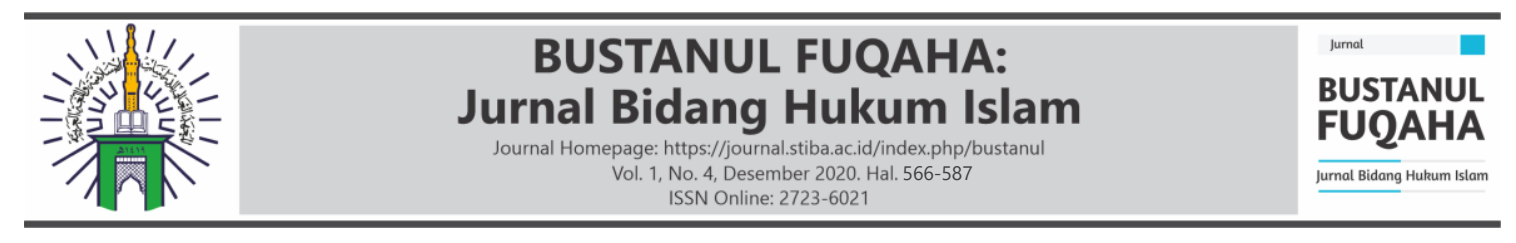

Pertama, apabila pembeli rida, maka barang itu terus ditangan dan jual beli itu dipandang sah. Kedua, membatalkan sama sekali akad jual beli segera setelah cacat itu diketahui. Ketiga, menuntut ganti rugi dari pihak penjual, seimbang denan cacat barang atau menerima potongan harga barang sebanding dengan cacatnya. Ibnu Abi Laila, Tsauri dan ahli-ahli ra'yu, sepakat bahwa apabila seseorang membeli barang yang diketahui ada cacatnya, lalu dia jual lagi, maka khiyārnya telah hapus.

Adanya hak khiar karena aib, diterangkan oleh sejumlah hadis Nabi saw., antara lain yang meriwayatkan oleh Imam Syafii dan Ashabus Sunan: Seseorang membeli budak di zaman Rasulullah saw. dan keadaan budak itu Masya Allah (bercacat). Kemudian dikembalikan budak itu karena aib (cacat) yang ada padanya. (Rupanya orang itu mengadukan kepada Rasulullah). Maka Rasulullah saw. memberikan keputusan hukum untuk mengembalikannya karena aib (cacat) itu. Orang yang dikenali putusan itu berkata "Ya Rasulullah dia telah memperkerjakannya!" Rasulullah menjawab: "itu adalah resiko jaminan".

Dalam hadis riwayat Bukhari menerangkan adanya seorang laki-laki yang melaporkan kepada Rasulullah saw. bahwa dia ditipu dalam jual beli, kemudian nabi menyatakan kepadanya keterangan ini menunjukan adanya hak Khiar aib. Dalam suatu riwayat melalui jalan Yūnus bin Bușair dan 'Abdi al-A'la suatu ditandakan bahwa kemudian engkau khiar setiap barang yang engkau beli dalam masa tiga malam jika engkau suka peganglah barangnya dan jika engkau tidak suka maka kembalikanlah. Sebaliknya pihak penjual pun kadang-kadang merasa tertipu karena kelicikan pembeli, menjemput dan memborong barang sebelum masuk pasar di mana penjual tidak mengetahui harga pasaran. Dalam keadaan seperti itu, pihak penjual mempunyai hal Khiar berdasarkan hadis Abi Hurairah, di mana Nabi saw. bersabda :

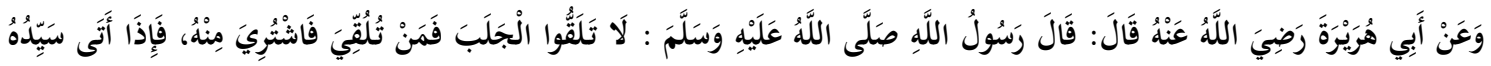

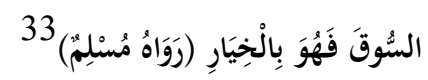

Artinya:

"Dari Abu Hurairah Radhiyallahu'anhu, dia berkata, "Rasulullah saw. Bersabda: Janganlah kalian rnenghadang barang yang dibawa (dari luar kota). Barang siapa menghadang dan membeli dari padanya, maka apabila penjual sampai ke pasar, baginya ada hak Khiar." (HR. Muslim).

Dasar mazhab Maliki menyatakan bahwa setiap yang berpengaruh pada nilai (maksudnya, mengurangi nilainya) merupakan cacat. ${ }^{34}$ Garis-garis syarak ini menunjukkan hikmah ajaran Islam yang luhur yang tidak menghendaki adanya pihak

\footnotetext{
${ }^{33}$ Imam Aṣ-Ṣan'ānī, "Subulus Salam," Jilid II, Syarat Syarat Jual Beli Dan Hal Hal Yang Di Larang Di Dalamnya, Hadis Ke 761 (Darul Hadist, n.d.), h. 29.

${ }^{34}$ Ibnu Rusyd, "Bidayatul Mujtahid," in Hukum-Hukum Cacat Pada Jual Beli Yang Bersifat Mutlak, n.d., h. 182.
} 


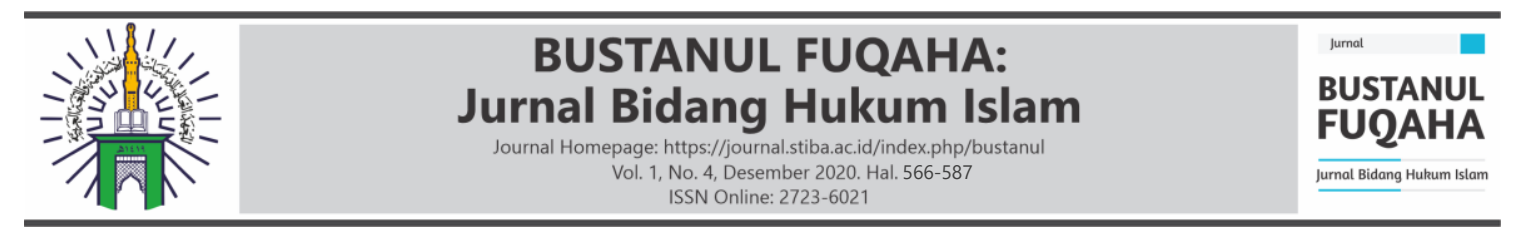

yang teraniaya dalam mu'amalah. Mu' amalah dikehendaki berlangsung tertib, lancar dan harmonis serta medatanglah kebaikan bagi semua pihak.

\section{Khiyār al-Ru'yah}

Khiyār al-Ru'yah, yaitu hak pilih bagi pembeli untuk menyatakan berlaku atau batalnya jual beli yang dilakukan terhadap suatu obyek yang belum dilihatnya ketika akad berlangsung. Sebelum akad terjadi, baik pembeli atau pun penjual belum terikat pada bebas menentukan (memilih), apakah transaksi itu dilangsungkan atau diurungkan (membatalkan). Dapat juga dikatakan bahwa Khiyār al-Ru'yahitu, masa memperhatikan keadaan barang, menimbang-nimbang dan berpikir sebelum mengambil keputusan melakukan transaksi atau akad.

Mengingat kemungkinan timbulnya akibat-akibat buruk jika dilakukan transaksi bagi orang yang gaib (tidak dilihat), maka segolongan fukaha mensyaratkan dilihatnya (di-ru'yah-nya) barang bagi sahnya jual beli.

Namun, menurut kenyataan banyak pula barang tidak mungkin diketahui kualitasnya secara langsung, yang apabila dibuka menimbulkan kerusakan barang. Misalnya makanan kaleng yang tidak terlihat secara jelas makanan yang ada di dalamnya dan hanya melihat daftar atau pun jangka waktu yang berlaku. Dalam keadaan tersebut boleh tidak di-ru'yah secara langsung dengan catatan ada hak khiar apabila ternyata ada kerusakan atau kualitasnya buruk. Dalam hubungannya dengan itu ada riwayat dan Abu Hurairah bahwa Nabi saw. bersabda: "Barang siapa membeli sesuatu yang belum dilihatnya, maka ada hak khiar baginya apabila dia telah melihatnya." (HR. Daruquṭi dan al-Baihaqi). Hadis tersebut daif karena dalam sanadnya terdapat 'Umar bin Ibrahim al-Kurdi, tetapi maknanya terpakai karena logis dan sejalan dengan prinsip khiar itu sendiri.

Dari keterangan ini dapat dipahami bahwa titik berat hak khiar itu berada pada pihak pembeli. Tetapi perdagangan itu secara barter, tentulah kedua belah pihak perlu Khiyār al-Ru'yah. Hikmah Khiyār al-Ru'yah ini dapat dipahami, yakni untuk menghindari penipuan. Kesamaran dan penyesalan yang mengundang sengketa bagi kedua belah pihak. Sebaliknya barang yang di-ru'yah dengan teliti dan tuntas sebelum dibeli, atau adanya hak khiar, setelah barang diteliti ternyata kualitasnya menyalahi pernyataan penjual, tentunya membelinya pun akan diurungkan ${ }^{35}$. Prinsip ini bertujuan membina kerukunan dan keharmonisan dalam bermuamalah. Adapun maslahat itulah yang menjadi tujuan syariat Islam.

\section{Manfaat khiar dalam Jual Beli}

Khiar merupakan hal yang sangat penting dalam transaksi jual beli untuk menjaga kepentingan, kemaslahatan dan kerelaan kedua belah pihak yang melakukan

\footnotetext{
${ }^{35}$ Dewi Sri Indriati, "Penerapan Khiyār Dalam Jual Beli,” Jurnal Ilmiah Al-Syar'iah 2, no. 2 (2016).
} 


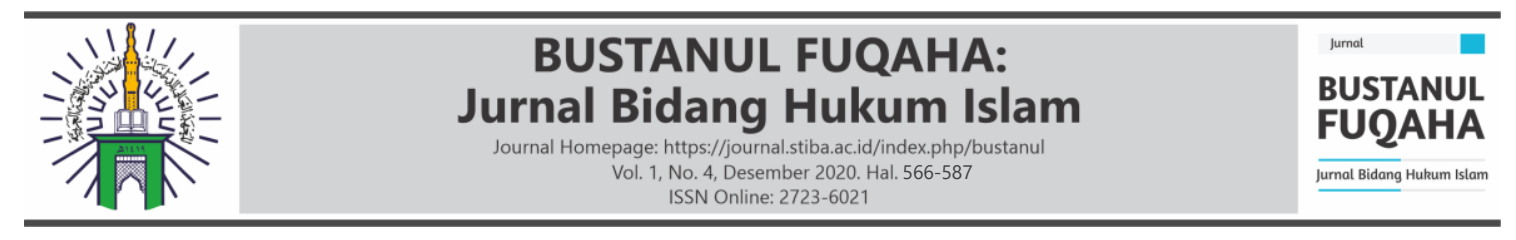

kontrak serta melindungi mereka dari bahaya yang mungkin menimbulkan kerugian bagi mereka. Adapun khiar hanya dapat dipergunakan dalam transaksi yang telah memenuhi rukun dan syarat tertentu dalam akad serta terdapat akibat hukum, akan tetapi akad tersebut memberi kesempatan untuk membatalkan salah satu pihak kerena salah satu dari keduanya mempunyai hak tertentu. Dengan demikian, khiar disyariatkan oleh Islam untuk memenuhi kepentingan yang timbul dari transaksi jual beli atau bisnis dalam kehidupan manusia. Khiar memiliki beberapa manfaat dalam transaksi jual beli yaitu sebagaimana dapat disimpulkan berikut ini:

1. Untuk membuktikan dan mempertegas adanya kerelaan dari pihak-pihak yang terikat dalam perjanjian/ transaksi jual beli.

2. Supaya pihak penjual dan pembeli merasa puas dalam urusan jual beli.

3. Untuk menghindarkan terjadinya penipuan dalam transaksi jual beli.

4. Untuk menjamin kesempurnaan dan kejujuran bagi pihak penjual dan pembeli.

Selain itu, dengan adanya khiar atau garansi pembeli dapat mengembalikan barang apabila barang yang dibeli tidak sesuai dengan ciri-ciri barang yang diinginkan atau barang tersebut rusak sebelum habis masa yang digaransikan. Selama masa yang digaransikan masih ada maka pembeli dapat mengembalikan barang tersebut. Dengan demikian, pembeli dalam hal ini tidak merasa dirugikan dan transaksi yang dilakukan dapat berlangsung atas dasar suka sama suka dan saling rida antara penjual dengan pembeli ${ }^{36}$.

\section{Bentuk Khiyār al-Majlis dalam Jual Beli Modern}

Zaman sekarang ini jual beli semakin maju dan mungkin sedikit berbeda dibandingkan jual beli yang dilakukan di zaman Rasulullah saw. yang akadnya secara langsung. Di era modern ini dengan teknologi yang semakin canggih yang memudahkan seseorang dalam melakukan transaksi melalui internet atau secara online. Salah satu contoh adalah penjualan produk secara online melalui internet seperti yang dilakukan oleh Shopee.com, bukalapak.com, berniaga.com, tokobagus.com, lazada.com, kaskus, olx.com, dan lain-lain. Beberapa bentuk khiyār dengan transaksi jual beli secara online yaitu:

\section{Aplikasi khiar dan Ketentuannya pada Aplikasi Belanja Online (studi pada aplikasi blibli.com dan Lazada)}

Cara pengembalian dan penukaran produk-produk yang telah dibeli dari www.blibli.com dilakukan sesuai dengan ketentuan-ketentuan yang tercantum dalam kebijakan pengembalian (return policy) yang ditetapkan oleh masing-masing penjual (merchant) produk-produk. Secara umum, Blibli.com hanya menerima pengembalian produk cacat produksi. Produk yang akan dikembalikan harus dalam kondisi baru dan

${ }^{36}$ Ela Eliska, “Analisisis Eksistensi Khiyār Dalam Akad Jual Beli (Studi Perbandingan Empat Mazhab) Skripsi (Banda Aceh: Fak. Syari’ ah Dan Hukum UIN Ar Raniri, 2017)," Manfaat Khiyār Dalam Akad Jual Beli. Khiyār, n.d., h. 133-134. 


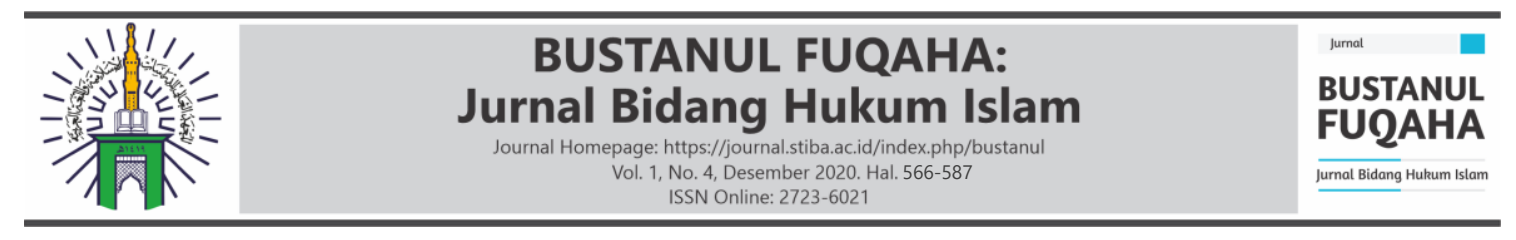

belum digunakan. Untuk produk-produk yang dilengkapi dengan segel garansi, Segel garansi tersebut harus dalam keadaan utuh.

Blibli.com memfasilitasi proses pengembalian atau penukaran produk yang telah dibeli dengan menyediakan halaman return policy. Pada halaman yang disediakan, pembeli dapat melaporkan kerusakan produk dengan memberikan foto dan deskripsi singkat mengenai kerusakan produk tersebut dalam kurun $1 \times 24$ jam dari waktu Anda menerima produk. Laporan kerusakan harus disertai dengan nomor pemesanan (order number). Setelah permintaan pengembalian (return request) diterima dan diproses oleh customer service center blibli.com, maka customer service akan segera menghubungi pembeli melalui alamat surat elektronik (email) atau telepon untuk mengkonfirmasikan return request. Apabila return request disetujui, maka customer service akan memberikan informasi mengenai metode pengiriman produk yang dikembalikan ${ }^{37}$.

Sistem di Lazada juga tidak jauh berbeda dengan situs di atas, proses pengembalian di lazada dimulai dengan melakukan $\log$ in pada situs tersebut. Setelah itu mencari "My Order" kemudian mengklik return. Dalam halaman tersebut, pembeli mengisi formulir pengembalian secara online, mencetaknya dan kemudian mengirimkannya bersamaan dengan produk yang ingin ditukar atau dikembalikan. ${ }^{38}$

\section{Jual Beli Pre Order}

Fenomena berbisnis online ini tidak sedikit menimbulkan kritik atau keluhan atas ketidakpuasan customer, baik pada akad pre order maupun ready stock. Pada akad pre order seperti yang sudah disebutkan diatas bahwa barang yang ditawarkan ialah barang contoh yang kemudian dijual dengan cara pemesanan dahulu kemudian proses pembuatan sesuai kriteria yang disebutkan.

Dalam online shop bukan hanya dalam akad pre order tapi juga dalam akad lainnya, kekurangan bisnis online ini ialah barang yang ditampilkan merupakan sebuah display atau gambar contoh yang kemudian terkadang menimbulkan perbedaan perspektif atau ekspektasi yang berbeda-beda pada pembeli sehingga kemudian menimbulkan kekecewaan saat barang diterima, namun hal ini merupakan sebuah resiko dari transaksi pada jual beli online, di mana pembeli maupun penjual seakan maklum atau sudah menjadi fenomena yang lumrah akan hal ini, padahal dalam Islam kesempurnaan sebuah transaki atau akad ditandai akan kerelaan di antara penjual maupun pembeli yang berakad. Oleh karena itu, dalam transaksi pre order dalam online shop selain menampilkan barang contoh sebagai display untuk ditawarkan kepada pembeli, penjual pun menyebutkan mengenai spesifikasi produk tersebut berupa material (bahan kain) yang digunakan serta ukuran yang dijelaskan secara spesifik, yang

\footnotetext{
${ }^{37}$ Khiyār (Hak Untuk Memilih) Dalam Transaksi On-Line: Studi Komparasi Antara Lazada, Zalara Dan Blibli," Falah: Jurnal Ekonomi Syariah 1, No. 1 (2016): h. 59.

${ }^{38}$ Khiyār (Hak Untuk Memilih) Dalam Transaksi On-Line: Studi Komparasi Antara Lazada, Zalara Dan Blibli," Falah: Jurnal Ekonomi Syariah 1, No. 1 (2016): h. 59-60.
} 


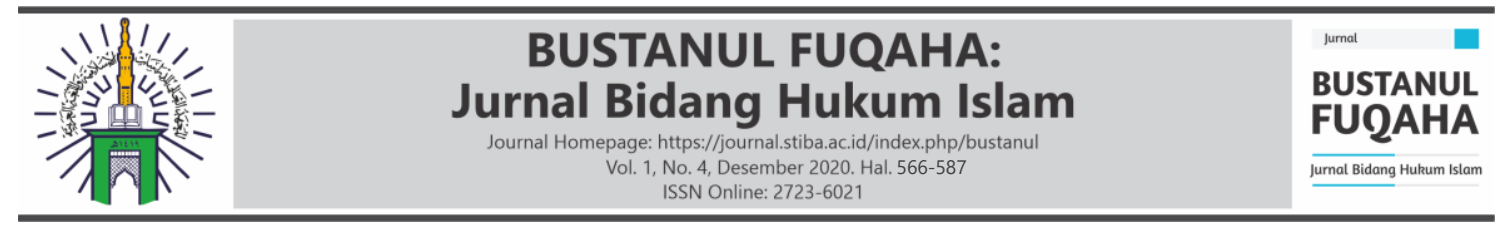

kemudian spesifikasinya dapat diminta lebih detail oleh pembeli kepada penjual untuk menghindari terjadinya perbedaan antara barang yang dipesan dan diterima.

Pre order adalah barang pesanan yang belum dibuatkan. Pre ordermemungkinkan konsumen untuk menjamin pengiriman segera saat rilis, produsen dapat mengukur berapa banyak permintaan yang akan ada dan dengan demikian ukuran produksi awal berjalan, dan penjual dapat yakin akan penjualan minimum. Selain itu, tingkat suku bunga pre order yang tinggi dapat digunakan untuk meningkatkan penjualan lebih jauh.

Pada jual beli online shop akad pre order seperti yang telah diidentifikasi, bahwasannya dalam online shop bersamaan dengan proses diterimanya barang yang telah dipesan, maka customer akan memberikan sebuah komentar yang merupakan sebuah kepuasan customer terhadap barang yang telah dipesan atau erringg disebut testimoni, dengan testimoni tersebut maka dapat ditinjau oleh owner online shop mengenai kepuasan maupun kritik customer, Kemudian bila ada suatu kecatatan barang atau ketidakpuasan customer terhadap barang yang dipesan seperti yang telah disebutkan di atas, maka owner online shop menawarkan opsi berupa pengembalian barang kepada pihak online shop dan pengembalian uang kepada pihak pembeli atau opsi berupa pengembalian barang dengan barang baru. Pihak online shop memberikan hak Khiar secara tidak langsung berupa:

a. Khiyār al-Majlis pada saat customer memberikan testimoni saat barang diterima.

Lama waktu selama berlangsungnya transaksi pre order dalam online shop dapat diartikan sebagai dua orang yang berakad yang masih dalam satu majlis transaksi karena keduanya belum berpisah karena keduanya masih terikat akad dari awal pemesanan, pengerjaan barang pesanan sampai kemudian barang diterima.

b. Khiyär al- 'Aib yang berlangsung dalam online shop dapat dilihat saat customer menerima barang pesananya, saat terdapat cacat atau aib maka Khiar aib pun berlangsung, dimana customer diberikan hak untuk memilih dan melihat brarang pesanannya kemudian bila menemukan sebuah kecatatan maka owner online shop memberikan gantinya.

Aib atau kecatatan barang dapat berupa sebuah kesalahan owner online shop dalam proses sortir barang (terlewat saat mensortir barang yang cacat), namun juga dapat berupa kekurangpuasan customer pada barang yang diterima (seperti kesalahan ukuran atau warna barang) yang kemudian membuat owner online shop memberikan sebuah hak khiar, yaitu berupa Khiyār al- 'Aib atas barang produksinya. ${ }^{39}$

\section{Hukum Khiyār al-Majlis Menurut Jumhur Ulama dan Imam Malik Terhadap Jual Beli Modern}

Dengan semakin banyaknya pengguna internet di seluruh dunia, bisnis online menjadi salah satu hal yang menjamur akhir- akhir ini. Di Indonesia sendiri banyak sekali

\footnotetext{
${ }^{39}$ Dafiqa Hasanah, Mulyadi Kosim, Suyud Arif. "Konsep Khiar Pada Jual Beli Pre Order Online Shop Dalam Perspektif Hukum Islam.” 255-251
} 


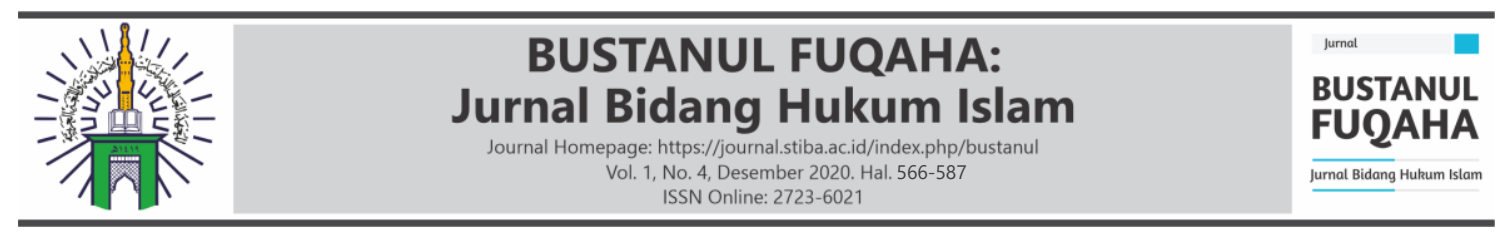

terdapat bisnis online, baik dalam skala kecil hingga besar. Dengan menjamurnya bisnis online yang mengandalkan kepercayaan antara pembeli dan pedagang ini, tingkat penipuan dalam bisnis online pun semakin meningkat. Di Indonesia sendiri, keberadaan bisnis online syariah (bisnis berbasis syariat) bisa dikatakan mulai berkembang. Kini semakin banyak masyarakat yang sadar akan pentingnya bisnis yang bersih, jujur dan sesuai dengan hukum Islam. Keberadaan bisnis online syariah ini juga tak terlepas dari peran perbankan syariah yang tumbuh secara positif di Indonesia. Sistem ekonomi syariah yang kini tengah populer di masyarakat membuat banyak orang beralih ke bisnis online yang sesuai dengan aturan Islam ini. Lalu apakah jual beli ini sesuai dengan pendapat jumhur ulama dan Imam Malik.

Pada dasarnya, bisnis online ini sama dengan bisnis offline seperti biasanya. Yang membedakan keduanya hanya lokasi atau tempat bisnis itu dijalankan. Dalam bisnis offline, terdapat toko atau tempat tetap yang digunakan untuk menjual barang atau jasa, sedangkan bisnis online menggunakan media internet sebagai tempat berjualan sekaligus media berpromosi. Antara pembeli dan penjual saling tak tatap muka dan transaksi dilakukan atas dasar kepercayaan. ${ }^{40}$

Khiar sebagai hak memilih yang diberikan kepada kedua belah pihak yang berakad (penjual dan pembeli) merupakan hak yang diberikan oleh Islam sebagai salah satu bukti sempurnanya Islam mengatur sebuah transaksi, bahwa diluar rukun dan syarat akad jual beli, Islam pun memberikan sebuah hak sebelum melanjutkan akad agar kedua belah pihak merasa saling rida akan akad yang telah dijalankannya, sebagaimana Allah swt. berfirman dalam Q.s. Al-Nisā'/3: 29,

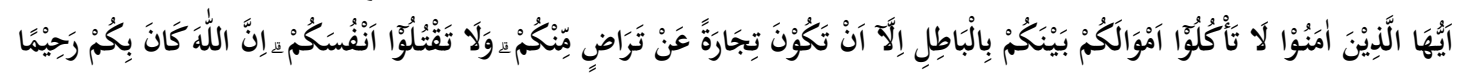
Artinya:

"Wahai orang-orang yang beriman! Janganlah kamu saling memakan harta sesamamu dengan jalan yang batil (tidak benar), kecuali dalam perdagangan yang berlaku atas dasar suka sama suka di antara kamu. Dan janganlah kamu membunuh dirimu. Sungguh, Allah Maha Penyayang kepadamu"41.

\section{Online Shop}

Praktek jual beli akad pada online shop sama halnya dengan jual beli akad salam hanya saja dilakukan tanpa face to face tapi menggunakan internet. Jual beli dalam online shop menampilkan barang berupa display dan deskripsi barang tersebut kepada customer kemudian customer memesan dengan rincian ukuran dan warna dari barang yang diinginkan kemudian barang pesanan akan dikerjakan dengan perjanjian lama waktu pengerjaan yang telah disepakati kemudian setelah barang jadi maka barang akan Negara."

${ }^{40}$ Tira Nur Fitria, "Bisnis Jual Beli Online (Online Shop) Dalam Hukum Islam Dan Hukum 2012), h. 29.

\footnotetext{
${ }^{41}$ Kementrian Agama. R.I, "Alquran," Alquran Terjemah Aljamil (bekasi: Cipta Bagus Sagara,
} 


\begin{tabular}{|c|c|c|}
\hline 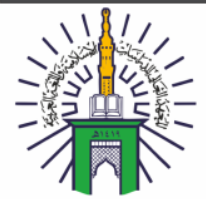 & 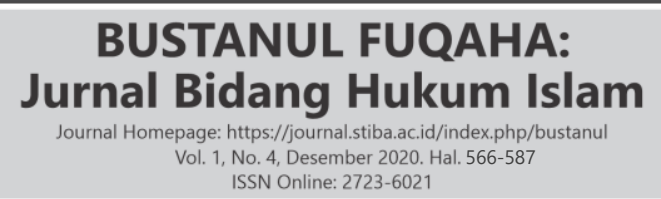 & $\begin{array}{l}\text { jurnal } \\
\text { BUSTANUL } \\
\text { FUQAHA } \\
\text { Jumal Bidang tukum slam }\end{array}$ \\
\hline
\end{tabular}

dikirim kepada customer dengan jasa ekspedisi hingga diterimanya barang ditangan customer, kemudian khiar dalam jual beli online shop terjadi secara tidak langsung ketika customer memberikan testimonial kepada owner online shop berupa kepuasan customer, kekecewaan atau pun komplain at as barang yang diterima dapat dikategorikan sebagai Khiyār al-Majlis karena pembeli dan penjual masih dalam satu ikatan transaksi.

Setelah itu, testimonial tersebut akan direspon oleh owner, yang apabila terdapat kekecewaan maka owner akan memberikan respon berupa sebuah penawaran return atau pengembalian barang atau uang bilamana barang yang diterima rusak atau terdapat cacat, dalam hal ini Khiyār al- 'Aib berlangsung. Oleh karena itu, meskipun jual beli online dihalangi oleh keterbatasan internet tetapi tidak justru membuat nilai nilai transaksi dalam Islam yang dianjurkan menjadi hilang, seperti praktek khiar dalam transaksi online shop ini yang terjadi secara tidak langsung. Jadi jual beli modern ini hukumnya boleh sebagaimana sabda Rasulullah saw.:

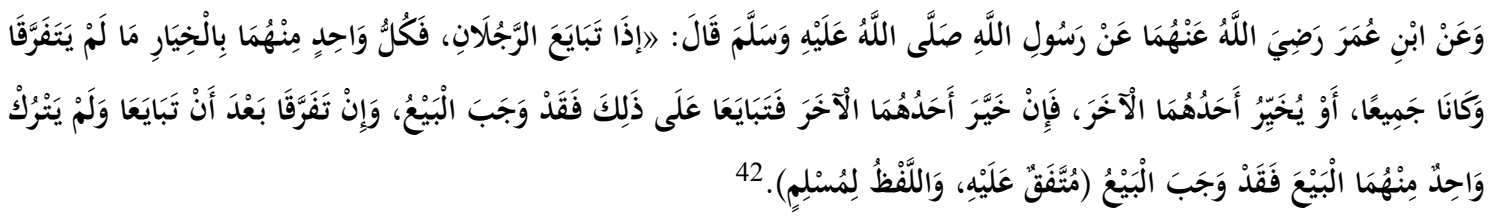

Artinya:

"Dari Ibnu 'Umar ra., dari Rasulullah saw. bersabda, "Apabila dua orang melakukan jual beli, maka masing-masing dari keduanya mempunyai hak khiar (memilih antara membatalkan atau meneruskan jual beli) selama mereka belum berpisah atau masih bersama; atau jika salah seorang di antara keduanya menentukan khiar kepada yang lainnya. Jika salah seorang menentukan khiar pada yang lain, lalu mereka berjual beli atas dasar itu, maka jadilah jual beli itu. Jika mereka berpisah setelah melakukan jual beli dan masing-masing dari keduanya tidak mengurungkan jual beli, maka jadilah jual beli itu." (Muttafaq 'Alaih, dan lafaz hadis ini menurut riwayat Muslim)

Dalam hadis di atas terdapat petunjuk adanya Khiyār al-Majlis bagi kedua pihak pelaku jual beli sampai keduanya berpisah badan. Jumhur ulama dari sekelompok sahabat di antaranya 'Ali bin Abi Țalib, Ibnu 'Abbās dan Ibnu 'Umar dan lainnya. Itu juga yang dipegang oleh kebanyakan kalangan tabiin dan Asy-Syafii, Ahmad, Ishaq dan Imam Yahya mereka mengatakan: perpisahan yang membatalkan khiar yaitu sesuatu yang dinamakan perpisahan secara adat kebiasaan. Seperti dalam rumah yang sempit dengan cara salah seorang keluar darinya, dan dalam rumah yang besar dengan cara berpindah dari tempatnya ke tempat yang lain dengan dua langkah atau tiga langkah. Perpisahan tersebut ditunjukkan dengan perbuatan Ibnu Umar yang terkenal. Bila kedua

\footnotetext{
"22Imam Ash-Ṣan’āni, "Subulus Salam Syarah Bulughul Maram,” [Shahih, Al-Bukhari (2107), Dan Muslim (1531)], 2008, h. 388.
} 


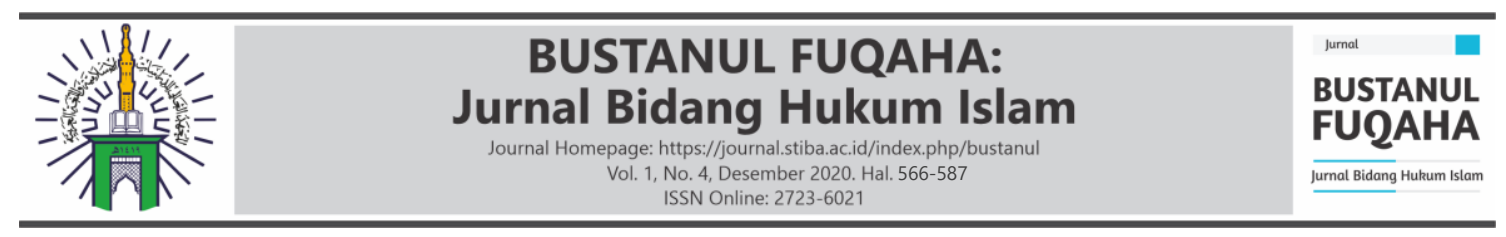

pihak semuanya berdiri dan pergi bersama-sama maka hak khiar tetap ada. Mazhab ini berargumentasi dengan hadis yang Muttafaq 'Alaih ini.

Mereka mengatakan, maksud berpisah dengan perkataan dan maksud berpisah di sini berupa perpisahan antara perkataan penjual "aku jual dengan harga sekian" atau perkataan pembeli "aku beli". Mereka mengatakan, maka pembeli mempunyai hak khiar pada perkataannya: "aku beli" atau dia meninggalkannya. Adapun penjual mempunyai hak khiar sampai pembeli mewajibkan jual beli. Tidak dipungkiri lagi kelemahan dan kebatilan pendapat ini. Dengan demikian, mengabaikan faedah hadis yang sudah diyakini setiap penjual atau pembeli dalam gambaran khiar ini bahwa tidak ada transaksi dari keduanya, sehingga khiar tersebut menghilangkan faedah dan lafaz hadis tertolak, maka pendapat yang benar adalah pendapat ini ${ }^{43}$.

\section{Jual Beli Barang yang Tidak Tampak dan Disifati}

Barang yang dijual ada dua macam; barang yang tampak serta dapat dilihat. Dalam hal ini tidak ada perselisihan tentang dibolehkannya berjual beli. Lalu bagaimana jika barang yang akan kita beli tidak dilihat namun penjual hanya memberitahukan bentuk dan sifat barang tersebut. Pada hal ini ulama berbeda pendapat, namun kami akan menyebutkan pendapat ulama yang membolehkannya di antaranya:

a. Malik dan kebanyakan ulama Madinah berpendapat diperbolehkan menjual barang yang tidak tampak berdasarkan sifat yang dibolehkan, jika ketidaktampakkannya menjamin tidak berubah sifatnya sebelum diterima.

b. Sedangkan Abu Hanifah mengatakan dibolehkan menjual barang yang tidak tampak tanpa adanya sifat, kemudian bagi si pembeli boleh melakukan Khiyār jika melihatnya. Ia boleh melangsungkan jual belinya atau menolaknya.

Begitu juga barang yang dijual berdasarkan sifat, di antara syaratnya menurut mereka yaitu adanya khiar (hak memilih antara meneruskan akad atau menolak) ketika melihat, jika sesuai dengan sifatnya. Sedangkan menurut Malik bahwa jika sesuai dengan sifatnya, maka menjadi keharusan. Pendapat lain di dalam mazhab Maliki mengatakan dibolehkan jual beli barang yang tidak tampak tanpa ada sifat dengan syarat khiar yaitu khiar ketika melihat.

Malik berpendapat bahwa ketidaktahuan yang disertai dengan tidak adanya sifat berpengaruh pada kelangsungan jual beli. Tidak ada perbedaan menurut Malik bahwa sifat hanya menggantikan barang yang nyata, karena tidak tampaknya barang yang dijual atau karena kesulitan untuk diperlihatkan dan sesuatu yang dikhawatirkan mengalami kerusakan karena sering diperlihatkan. Oleh karena itu, dia membolehkan jual beli dengan memperlihatkan sifatnya dan menurutnya tidak dibolehkan jual beli senjata dalam sarungnya dan juga pakaian yang dilipat dalam lipatannya, hingga dibeberkan atau diperlihatkan sesuatu yang terdapat dalam sarung senjata tersebut.

\footnotetext{
${ }^{43}$ Imam Aṣ-Ṣan'ānī, “Subulus Salam,” Bab Khiyār (Memilih) (Darul Hadist, n.d.), h.45-46.
} 


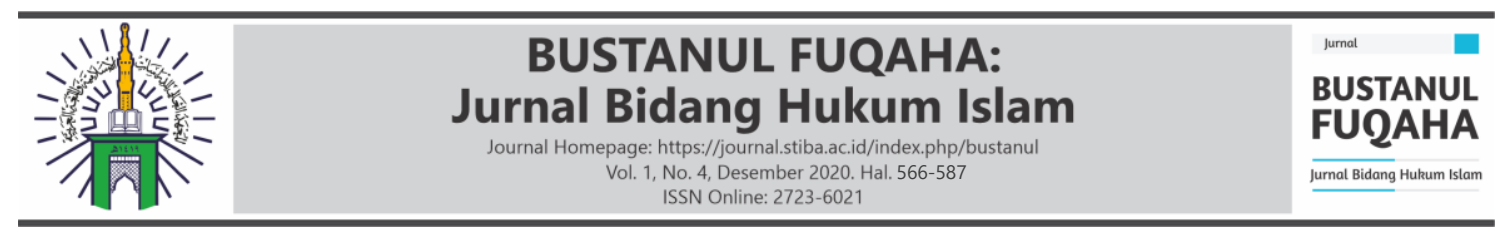

Abu Hanifah berhujah dengan hadis yang diriwayatkan dari Ibnu Al-Musayyib, bahwa dia berkata, "Para sahabat Nabi saw. mengatakan, kami ingin agar 'Utsman bin 'Affān dan 'Abd. Al-Raḥmān bin 'Auf saling berjual beli sehingga kami bisa mengetahui siapa di antara keduanya yang paling bersungguh-sungguh dalam perdagangan. Maka 'Abd. Al-Raḥmān membeli dari 'Utsman bin 'Affān seekor kuda yang berada di tanahnya yang lain dengan harga empat puluh ribu atau empat ribu. Kemudian dia menyebutkan kelanjutan dari hadis tersebut dan di dalamnya terdapat jual beli barang yang tidak tampak secara mutlak." Adapun menurut Abu Hanifah harus mensyaratkan jenis ${ }^{44}$.

\section{KESIMPULAN}

Berdasarkan uraian di atas, maka dapat diambil kesimpulan sebagai berikut:

1. Fikih Khiyār al-Majlis menurut pendapat Jumhur ulama adalah mubah/boleh, dengan menetapkan adanya jual beli di antara keduanya tidak saling menawar, keduanya mempunyai hak khiar (memilih antara membatalkan atau meneruskan jual beli) selama mereka berpisah secara fisik atau masih bersama, bila salah satu dari keduanya mensyaratkan adanya khiar dalam tempo tertentu untuk meneruskan jual beli sebelum berpisah, maka terjadilah jual beli pada saat itu dan batallah ketentuan berpisah. Perpisahan yang membatalkan khiar yaitu sesuatu yang dinamakan perpisahan secara adat kebiasaan. Perpisahan tersebut ditunjukkan dengan perbuatan Ibnu 'Umar yang terkenal. Bila kedua pihak semuanya berdiri dan pergi bersama-sama maka hak khiar (pilih) tetap ada.

2. Fikih Khiyār al-Majlis menurut Imam Malik adalah tidak boleh. Adapun khiar yang boleh diklasifisikan ke dalam dua bentuk yaitu khiar syarat dan khiar aib. Mazhab Maliki menyatakan bahwa kedua bentuk khiar itu dibolehkan dalam jual beli, dengan tujuan untuk menyelamatkan pembeli dari unsur-unsur penipuan yang dapat menyebabkan terjadinya kerugian.

3. Dalam jual beli modern atau online shop, Khiyār al-Majlis (hak untuk meneruskan atau membatalkan jual beli) antara penjual dan pembeli dapat dilakukan bila salah satu dari keduanya mensyaratkan adanya khiar dalam tempo tertentu dan mereka masih dalam satu transaksi sampai ia menerima barangnya dan hal ini sesuai dengan pendapat jumhur ulama sedangkan menurut Imam Malik pembeli dapat melakukan khiar syarat sebelum pengiriman barang maupun khiar aib ketika barang yang di terima terdapat cacat.

\section{DAFTAR PUSTAKA}

Amiruddin, M. M. (2016). Khiar (hak untuk memilih) dalam Transaksi On-Line: Studi Komparasi antara Lazada, Zalara dan Blibli. Falah: Jurnal Ekonomi Syariah, 1(1), 47-62. https://doi.org/10.22219/jes.v1i1.2695.

\footnotetext{
${ }^{44}$ Ibnu Rusyd, "Bidayatul Mujtahid,” Jual Beli Barang Yang Tidak Nampak Dan Disifati (Darul Hadist, n.d.), 173-174.
} 


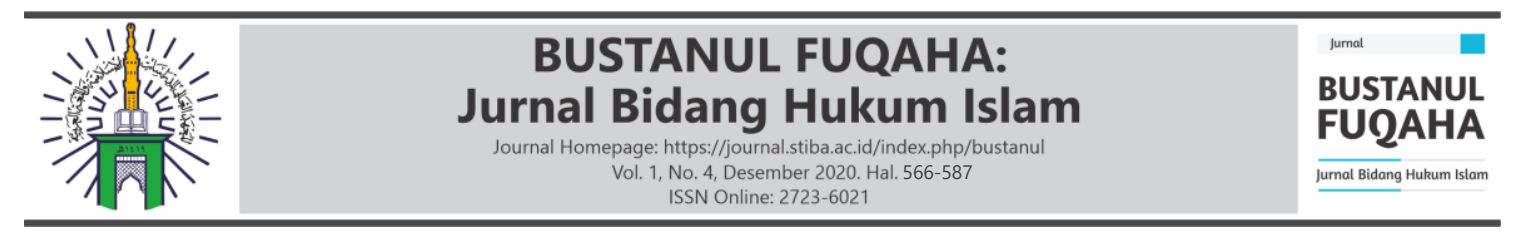

Az-Zuhaili, W. (2012). Fiqh Imam Syafie I, terj. Muhammad Afifi, dkk.

Eliska, E. (2017). Analisisis Eksistensi Khiyār Dalam Akad Jual Beli (Studi Perbandingan Empat Mazhab). Skripsi: (Banda Aceh: Fak. Syari'ah Dan Hukum UIN Ar Raniri).

Fitria, T. N. (2017). Bisnis jual beli online (online shop) dalam Hukum Islam dan Hukum Negara. Jurnal Ilmiah Ekonomi Islam, 3(01), 52-62. http://dx.doi.org/10.29040/jiei.v3i01.99

Hasanah, D., Kosim, M., \& Arif, S. (2019). Konsep Khiyar pada Jual Beli Pre Order Online Shop dalam Perspektif Hukum Islam. IQTISHODUNA: Jurnal Ekonomi Islam, 8(2), 249-260.

Imam Ash-shan'ani. (t.th). "Subulus Salam.” Jilid II Bab Khiyar (Memilih). Darul Hadist, n.d.

_. "Subulus Salam Syarah Bulughul Maram.” Jilid II Bab Khiyar (Memilih). Darul Hadist, n.d.

Ibnu Rusyd. (t.th). "Bidayatul Mujtahid.” In Bab Khiyar (Memilih)

Ibnu Rusyd. (t.th). "Bidayatul Mujtahid.” In Hukum-Hukum Cacat Pada Jual Beli Yang Bersifat Mutlak.

Imam Ash-shan'ani. "Subulus Salam.” In Jilid II Bab Khiyar (Memilih), h.45. Darul Hadist, n.d.

—. "Subulus Salam." In Bab Khiyar (Memilih) Shahih, Al-Bukhari (2117) Dan Muslim (1533), h. 48. Darul Hadist, n.d.

Indriati, D. S. (2016). Penerapan Khiyar Dalam Jual Beli. Jurnal Ilmiah Al-Syir'ah, 2(2).. https://doi.org/10.30984/as.v2i2.220.

—. (2012). “Alquran Terjemah Aljamil.” In Alquran, h. 275. Bekasi: Cipta Bagus Sagara.

Iskandar, A., \& Aqbar, K. (2019). Reposisi Praktik Ekonomi Islam: Studi Kritis Praktik Ekonomi Islam di Indonesia. NUKHBATUL'ULUM: Jurnal Bidang Kajian Islam, 5(1), 39-53.

Languyu, N. (2015). Kedudukan Hukum Penjual dan Pembeli dalam Bisnis Jual Beli Online. Lex et Societatis, 3(9).

Muhammad, Abi Abdillah. "Shahih Bukhari Juz III.” Beirut: Dar Al-Kutub Al-Ilmiyah, 1992.

Rusyd, Ibnu. (t.th) "Bidayatul Mujtahid." In Hasan. HR. Al Jarujdid (567), AdDaruquthni (51213), Al Hakim (2122), Al Baihaqi (3154), Dinllai Shahift Oleh AdzDzahabi Dalam At-Talkhish, h. 225.

Wijaya, H. (2018). Takyif Fiqh Pembayaran Jasa Transportasi Online Menggunakan Uang Elektronik (Go-Pay Dan OVO). NUKHBATUL'UL UM: Jurnal Bidang Kajian Islam, 4(2), 187-203. 